
VOLUME 10 NOMOR 4 AGUSTUS 2021

ISSN : 2303-1514 | E-ISSN : 2598-5949

DOI : http://dx.doi.org/10.33578/jpfkip.v10i4.8015

https://primary.ejournal.unri.ac.id/index.php/JPFKIP

\title{
SHAPING THE CHILDREN'S SOCIAL CARING CHARACTERS THROUGH GOBAK SODOR GAME
}

\author{
Imro'atul Khoiriyah ${ }^{1}$, Erik Aditia Ismaya ${ }^{2}$, Deka Setiawan ${ }^{3}$ \\ ${ }^{1,2,3}$ Program Studi Pendidikan Guru Sekolah Dasar, FKIP Universitas Muria Kudus, Indonesia \\ 1'imroatul960@gmail.com, ${ }^{2}$ erik.aditia@umk.ac.id, ${ }^{3}$ deka.setiawan@umk.ac.id

\section{PEMBENTUKAN KARAKTER PEDULI SOSIAL PADA ANAK MELALUI PERMAINAN GOBAK SODOR}

\begin{tabular}{|c|c|}
\hline ARTICLE HISTORY & ABSTRACT \\
\hline $\begin{array}{l}\text { Submitted: } \\
28 \text { Desember } 2020 \\
28^{\text {th }} \text { December } 2020\end{array}$ & $\begin{array}{l}\text { Abstract: This study aimed to determine the behavior of children aged 6-12 years and to } \\
\text { analyze the children behavior towards social care character values through playing gobak } \\
\text { sodor. The type of this study was qualitative descriptive which involved children aged 6-12 } \\
\text { years with low social awareness as the research subjects. Data were collected through } \\
\text { observation and interviews. Then, the data were analyzed by using the interactive model } \\
\text { analysis technique from Miles and Huberman (data reduction, data presentation, drawing } \\
\text { conclusions). The validity was examined by technique and source triangulation. Social care } \\
\text { was a behavior or action carried out by individuals consciously towards other individuals so as } \\
\text { to create interactions with wider community. In social life, especially in heterogeneous } \\
\text { communities, social care was required by individuals (children). Social care would become } \\
\text { learning when interacting with other children. Every interaction trained children to have high } \\
\text { social sensitivity towards friends and their environment. Social care for children could be } \\
\text { applied through a traditional Indonesian game known as Gobak Sodor. The results showed that } \\
\text { there was an increase in the character of social care after playing the traditional game, Gobak } \\
\text { Sodor. Social attitudes that were very striking were the attitude of responsibility, focus, } \\
\text { tolerance. }\end{array}$ \\
\hline
\end{tabular}

Accepted:

Keywords: social care, gobak sodor

05 Agustus 2021

$05^{\text {th }}$ August 2021

Published:

27 Agustus 2021

$27^{\text {th }}$ August 2021

\begin{abstract}
Abstrak: Penelitian ini bertujuan untuk mengetahui perilaku anak usia 6-12 tahun dan menganalisis perilaku anak dengan nilai karakter peduli sosial melalui permainan gobak sodor. Jenis penelitian ini adalah deskriptif kualitatif dengan subjek penelitian adalah anak usia 6-12 tahun yang memiliki kepedulian sosial rendah. Menggunakan teknik pengumpulan data berupa observasi dan wawancara. Analisis data menggunakaan teknik analisis model interaktif Miles dan Huberman (reduksi data, penyajian data, pengambilan keimpulan). Uji keabsahan menggunakan triangulasi teknik dan sumber. Peduli sosial adalah perilaku atau perbuatan yang dilakukan oleh individu secara sadar terhadap individu lain sehingga menciptakan interaksi dengan masyarakat luas. Dalam kehidupan bermasyarakat khususnya masyarakat heterogen, peduli sosial sangat diperlukan oleh individu (anak). Peduli sosial inilah yang akan menjadi pembelajaran saat melakukan hubungan atau interaksi dengan anak lain. Setiap interaksi yang dilakukan melatih anak untuk memiliki kepekaan sosial yang tinggi terhadap teman dan lingkungannya. Peduli sosial anak dapat diterapkan melalui permainan tradisional Indonesia yang sudah jarang dimainkan yaitu gobak sodor. Hasil penelitian menunjukkan bahwa ada peningkatan pada karakter peduli sosial setelah melakukan permainan tradisional gobak sodor. Sikap sosial yang sangat mencolok adalah sikap tanggung jawab, fokus, tenggang rasa.
\end{abstract}

Kata kunci: peduli sosial, gobak sodor

CITATION

Khoiriyah, I., Ismaya., E., A. \& Setiwan., D. (2021). Shaping the Children's Social Caring Characters through Gobak Sodor Game. Primary: Jurnal Pendidikan Guru Sekolah Dasar, 10 (4), 942-948. DOI: http://dx.doi.org/10.33578/jpfkip.v10i4.8015. 


\section{PENDAHULUAN}

Pendidikan karakter akan terbawa dari anak-anak hingga dewasa. Pendidikan karakter yaitu proses transformasi nilai-nilai kehidupan untuk ditumbuh kembangkan dalam kepribadian seseorang sehingga menjadi satu dalam perilaku kehidupan orang itu (Kesuma, 2013:5). Pendidikan karakter yang dilakukan setiap hari akan mendasar pada kehidupan seseorang dan menjadi ciri dari seseorang tersebut. Pendidikan karakter sangat diperlukan saat ini, karena banyak masalah sosial yang muncul seperti korupsi, pembalakan liar, kekerasan, kejahatan sosial, dan lainnya yang terjadi pada masyarakat Indonesia.

Novak menyatakan bahwa, karakter ialah campuran kompatibel dari seluruh kebaikan yang diidentifikasi oleh tradisi religius, cerita sastra, kaum bijaksana, dan kumpulan orang berakal sehat yang ada dalam sejarah (Lickona, 2012:81). Sebagaimana disebutkan Novak, setiap individu tidak memiliki semua nilai kebaikan tersebut, sehingga perlu diberikan stimultan atau pancingan agar individu dapat memiliki karakter baik. Karakter merupakan nilai tentang sesuatu yang diwujudakan dalam bentuk perilaku (Kesuma, 2013:11). Setiap perilaku individu diharapkan adalah perilaku yang baik dan bernilai positif. Sehingga dapat diterima oleh masyarakat luas. Echols dan Shadily menyatakan, karakter dalam bahasa Inggris berarti mengukir, melukis, memahatkan, atau menggoreskan (Suyadi, 2013:56). Berbeda dalam bahasa Indonesia, karakter berarti tabiat, sifat-sifat kejiwaan, akhlak atau budi pekerti yang membedakan seseorang dengan yang lain. Arti dari orang berkarakter adalah orang yang berkepribadian, berperilaku, bersifat, bertabiat, atau berwatak tertentu, dan watak tersebut yang membedakan dirinya dengan orang lain. Karakter terdiri dari nilai operatif, yaitu nilai dalam tindakan (Lickona, 2012:82). Seiring nilai tindakan menjadikan individu baik dan berlangsung lama serta dapat diandalkan individu tersebut pada situasi tertentu, dapat dikatakan bahwa individu tersebut berkarakter baik.

Pendidikan karakter adalah usaha untuk mendidik anak-anak agar dapat mengambil keputusan dengan bijak dan mempraktekkannya dalam kehidupan seharihari, sehingga mereka dapat memberikan kontribusi positif kepada lingkungannya (Megawangi, 2004:95). Pendidikan karakter sangat dianjurkan diterapkan pada anak usia dini. Kegagalan pendidikan karakter pada anak usia dini akan membentuk pribadi yang bermasalah saat dewasanya kelak. Pada usia tersebut anak berada pada masa kritis pembentukan karakter sehingga kegagalan pendidikan karakter sangat kecil terjadi.

Pendidikan karakter yaitu proses transformasi nilai-nilai kehidupan untuk ditumbuhkembangkan dalam kepribadian seseorang sehingga menjadi satu dalam perilaku kehidupan orang itu (Kesuma, 2013:5). Proses tersebut harus dilakukan sering dan dalam kehidupan sehari-hari sehingga dapat membentuk individu yang baik bagi dirinya sendiri dan lingkungannya. Pendidikan karakter, menurut Andayani dan Majid (2013:50) adalah sebuah upaya untuk membimbing perilaku manusia menuju standar-standar tertentu. Fokus pendidikan karaker yaitu pada tujuan etika, namun untuk praktiknya meliputi penguatan kecakapankecakapan penting yang mencakup perkembangan sosial.

Lickona (Ridwan, 2013) menyatakan ada tujuh hal yang melatar belakangi pendidikan karakter harus dilakukan, yaitu: Cara terbaik untuk menjamin anak-anak memiliki kepribadian yang baik dalam kehidupannya; Cara untuk meningkatkan prestasi akademik; Sebagai siswa tidak dapat membentuk karakter yang kuat bagi dirinya di tempat lain; Persiapan anak untuk menghormati pihak atau orang lain dan dapat hidup dalam masyarakat yang beragam; Berangkat dari akar masalah yang berkaitan dengan problem moral sosial, seperti ketidaksopanan, ketidakjujuran, kekerasan, 
pelanggaran kegiatan seksual, dan etos kerja (belajar) yang rendah; Persiapan terbaik untuk menyongsong perilaku di tempat kerja; dan Pembelajaran nilai-nilai budaya yang merupakan bagian dari kerja peradaban.

Sikap sosial adalah pemahaman individu dalam berperilaku, dan berpikir terhadap kehadiran orang lain secara nyata. Baik secara langsung maupun secara tidak langsung (Baron dan Byrne, 2004: 54). Hal ini membutuhkan banyak orang yang ada di sekitarnya, baik keluarga, maupun temannya. Menurut Utami (2011) sikap adalah kesadaran individu yang menentukan perbuatan yang nyata dalam kegiatan-kegiatan sosial. Berhubungan dengan banyak individu dalam kehidupan nyata dan berlangsung terus menerus. Secara umum, sikap sosial dilakukan oleh orang banyak. Bisa dalam kelompok kecil maupun kelompok besar. Sikap sosial dapat dilakukan berulang-ulang sehingga terjalin ketergantungan dengan individu lain dalam kehidupan bermasyarakat. Sikap sosial muncul karena adanya rangsangan yang ada di sekitar lingkungannya. Baik lingkungan sosial maupun budaya setempat, seperti keluarga, agama, adat istiadat, ekonomi, politik dan lain sebagainya.

Sikap sosial akan menciptakan interaksi sosial, yaitu komunikasi individu dengan individu lain, yang dapat menyebabkan suatu ikatan berupa perasaan sosial. Misalnya saling memberi dan menerima, setia kawan, tolong menolong dan lainnya. Banyak yang berpendapat bahwa sikap diajarkan oleh orang tua dan lembaga agama. Namun, pendapat tersebut perlu diubah bahwa sikap tercipta karena adanya rangsangan dari lingkungan sekitarnya. Lingkungan sekitar yang positif akan menciptakan individu yang memiliki kepekaan sosial tinggi pada lingkungan sekitarnya. Menurut Kurniati (2016: 89) Sikap sosial dibedakan menjadi dua yaitu sikap sosial positif dan sikap sosial negatif. Setiap sikap sosial tersebut dibagi lagi menjadi beberapa aspek,diantaranya: Sikap sosial positif, ada tiga aspek yaitu aspek kerja sama, aspek solidaritas, dan aspek tenggang rasa; Sikap sosial negatif, ada lima aspek yaitu stereotip, rasialisme, rasisme, prasangka sosial, egoisme.

Peduli sosial adalah perasaan bertanggung jawab atas kesulitan yang dihadapi oleh orang lain dimana seseorang terdorong untuk melakukan sesuatu untuk mengatasinya (Tabi'in, 2017: 1(1) 40-62). Jika sifat ini ditanamkan sejak dini akan berdampak positif dalam kehidupannya dimasa depan. Anak akan memproses dan mengingat pembelajaran bernilai positif tersebut, dan menggunakannya ketika berada di tengah masyarakat. Menurut Samani, peduli sosial merupakan sikap memperlakukan orang lain dengan penuh kebaikan dan kedermawanan, peka terhadap perasaan orang lain membantu orang yang membutuhkan pertolongan, tidak pernah kasar dan tidak menyakiti hati orang lain (Adi, 2016). Menjadikan individu berhatihati dalam bersikap dan memperlakukan orang lain. Individu menghormati hak individu lain.

Menurut Fauzi (2017: 2 (2) 27-29)

sumber kepedulian sosial ada dua yaitu: Bersumber dari cinta, yaitu kepekaan hati untuk merasakan apa yang dirasakan oleh orang lain atau sering disebut rasa empati. Rasa empati berarti individu dapat merasakan dan memahami apa yang dilakukan, dan dirasakan individu lainnya; Tidak karena alasan tertentu, yaitu kepedulian timbul dari hati terbuka mau berbagi dengan sesama tanpa didorong alasan dan imbalan apapun. Menurut Agung dan Asmira, (2018: 1 (2)) kepedulian sosial dibagi menjadi tiga yaitu: Kepedulian yang sering lebih mendesak, yaitu kepedulian akan kepentingan bersama pada hal-hal yang sering mendesak kita lakukan. Dilakukan dengan cara melakukan atau menahan sesuatu untuk kepentingan bersama; Kepedulian yang berlangsung saat suka maupun duka, yaitu keterlibatan individu untuk merasakan apayang dirasakan dan dialami individu lain.

Menurut (Adi 2016) ada tiga cara untuk membentuk sikap dan perilaku kepedulian sosial: Melalui Penerimaan, diperoleh melalui penerimaan atau 
konsekuensi yang diterima karena bersikap dan berperilaku peduli sosial; Dari informasi verbal, diperoleh dari kondisi dan keadaan individu sekitar yang memiliki sikap dan perilaku sosial rendah. Sehingga membuat indivdu tergerak hatinyauntuk berperilaku peduli sosial; Mengamati dan meniru, diperoleh dari individu yang diidolakan karena memiliki sikap dan perilaku peduli sosial tinggi. Menurut Agung dan Asmira, (2018: 1 (2)) ada dua hambatan untuk terbentuknya sikap sosial: Materealistis, sikap yang mengutamakan materi untuk memenuhi kebutuhan hidup; Egoisme, sikap bahwa semua tindakan individu harus terarah pada diri sendiri. Hal ini akan sangat mengganggu dan menghambat sikap sosial, karena sikap sosial mebutuhkan kerelaan hati atau keikhlasan.

Menurut Piaget permainan membentuk konsep keterampilan dan membentuk kognisi anak serta mengembangkan kognisis tersebut (Handoyo dan Yudiwinata, 2014). Dalam hal ini, permainan memiliki peran yang dapat menumbuhkan semangat kreatifitas dan kecerdasan pada anak. Piaget menyampaikan ada tiga tahap operasional konkrit yang akan dialami anak usia 7-11 tahun. Tahap tersebut yaitu: anak menghilangkan konsep egosentris, pada usia tersebut anak mulai mengenal permainan dan memainkannya dengan teman sebayanya, saat dewasa dengan tahap operasional formal anak dapat berkembang dengan baik.

Selain itu, kita juga harus melestarikan permainan tradisional Indonesia yang hampir punah. Permainan tradisional zaman dahulu banyak yang berisi pembelajaran untuk anak. Misalnya melatih kepekaan sosial anak, dan kerjasama antar anak. Salah satu permainan tersebut adalah Gobok Sodor. Gobak sodor merupakan permainan tradisional yang cara memainkannya dibutuhkan kerjasama antar pemain dalam satu kelompok.

Permainan tradisional dapat digunakan untuk menerapkan pendidikan karakter pada anak. Karena pada usia tersebut anak mengalami pembelajaran dari lingkungan. Pembelajaran ini akan dibawa anak hingga usia dewasa. Tentu yang diharapkan adalah pembelajaran yang bersifat positif, agar anak memiliki bekal dalam kehidupannya dimasa mendatang.

Usia 6-12 tahun adalah usia yang pantas dan matang jika diberi contoh dan diberi pengertian kebaikan. Contoh dan pengertian kebaikan ini akan terbawa hingga dewasa dan dapat digunakannya kelak. Anak rusunawa dengan perbedaan asal-usul, keluarga, dan ekonomi, sangat rentan terhadap perselisihan. Maka dari itu perlu adanya pencegahan dan pemberian pengertian dan informasi, agar tidak terjadi perselisihan yang berlanjut, dan menciptakan masyarakat yang damai.

\section{METODE PENELITIAN}

Penelitian ini menggunakan penelitian kualitatif deskriptif, dengan sumber data berdasarkan wawancara, catatan data lapangan, dokumen pribadi, gambar, dan lainnya. Data tersebut akan dideskripsikan oleh peneliti dengan stategi penelitian studi kasus. Subjek penelitian adalah anak dengan kepedulian sosial rendah. Sehingga dapat dilakukan cara untuk meningkatkan kepedulian sosial pada anak.

Penelitian dilakukan pada 6 informan atau subjek. Informan merupakan anak yang tinggal di rusunawa Bakalan Krapyak Kudus.penelitian dilakukan selama tiga kali yaitu:

1. Hari Jumat 17 Januari 2020, pukul 15.00 WIB- 17.30 WIB

2. Hari Minggu 19 Agustus 2020, pukul 08.00 WIB- 11.00 WIB

3. Hari Selasa 21 Agustus 2020, pukul 15.00 WIB - 17.30 WIB

Penelitian dilakukan untuk mengetahui perilaku anak dari hasil wawancara dengan orang tua anak, observasi perilaku anak dalam kegiatan sehari-hari, wawancara anak, dan bermain permainan gobak sodor. Teknik analisis data menggunakan narasi deskriptif. 


\section{HASIL DAN PEMBAHASAN}

Penelitian menghasilkan gambaran kehidupan sehari-hari anak di rusunawa Bakalan Krapyak Kudus. Hasil penelitian didapat dengan cara melakukan wawancara dan observasi. Adapun hasil penelitiannya sebagai berikut:

\section{Wawancara dan Observasi Sebelum Bermain Gobak Sodor}

4 dari 6 informan telah mengetahui tentang peduli sosial, mereka akan memberikan bantuan pada teman yang membutuhkan bantuan, menjenguk teman jika sakit, melarang teman agar tidak mengolokolok teman lain, dan jika ada yang jatuh dari sepeda akan diberi obat. Jawaban tersebut didapat setelah peneliti memberikan beberapa pertanyaan inti yaitu bagaimana sikap kalian jika ada teman yang jatuh, bagaimana tanggapan kalian jika ada teman yang mengolok-olok teman yang lain, bagaimana jika ada teman yang sedang sakit. Saat melakukan observasi pada anak di tempat tinggalnya dan wawancara dengan orang tua anak, ditemukan bahwa 4 dari 6 informan tersebut dalam kegiatan sehari-hari memang sudah memiliki kepedulian sosial. Misalnya membantu orang tua saat sedang repot, menjaga adik, mengajari mengerjakan PR, membantu teman saat mengalami kesusahan, dan menjenguk teman yang sakit pada saat itu bertepatan ada teman yang sakit. Mereka tidak sungkan untuk menjenguk temannya tersebut.

2 dari 6 informan belum memiliki kesadaran kepedulian sosial, mereka memberikan jawaban yang berbeda dari 4 informan lainnya ketika diberikan pertanyaan yang sama. Mereka menjawab akan menertawakan teman yang jatuh, ikut mengolok dan menjahili teman lainnya. Saat melakukan observasi pada anak di tempat tinggalnya dan wawancara dengan orang tua anak, ditemukan bahwa 2 informan tersebut lebih sering bermain HP, meskipun terkadang membantu orang tua saat repot. Masih mau menolong teman saat temannya jatuh setelah ditertawakan.
3 dari 6 informan mengatakan belum pernah memainkan permainan gobak sodor, belum mengetahui permainan gobak sodor. Meskipun ada jawaban jika mengetahui beberapa permainan tradisional lainnya, seperti betengan, jungkat-jungkit, dakon, dan lompat tali. Jawaban didapat ketika diberi beberapa pertanyaan inti seperti apakah mengetahui permainan gobak sodor, pernah memainkannya, dan mengetahui permainan tradisional lainnya.

3 dari 6 informan lainnya telah mengetahui dan pernah bermain gobak sodor, mereka mengatakan bahwa bermain gobak sodor mengasikkan, membuat hati gembira, sudah jarang dimainkan, membuat fokus dan ingin memainkannya kembali.

\section{Sesudah Bermain Gobak Sodor}

Seluruh informan telah memberikan jawaban yang hampir mirip ketika diberi pertanyaan yang sama dengan sebelum bermain gobak sodor. Mereka akan membantu teman saat ada yang kesulitan, memberi sumbangan, menjenguk ketika ada yang sakit dan mendoakan cepat sembuh, tidak mengganggu teman lain. Hal ini juga terlihat saat observasi, mereka sudah tidak mengganggu, mengolok, dan mengurangi permainan dengan HP.

\section{SIMPULAN DAN REKOMENDASI}

Berdasarkan hasil penelitian diambil simpulan sebagai berikut:

Perkembangan proses pembentukan karakter peduli sosial pada anak di rusunawa Bakalan Krapyak Kudusengan bermain gobak sodor memberi dampak positif pada anak. Anak jadi memiliki kepercayaan diri yang lebih baik, melatih anak lebih fokus, lebih bertanggung jawab, lebih peka terhadap lingkungan sekitar, dapat mengontrol diri lebih baik, meningkatkan komunikasi, melatih kerjasama tim, melatih kesabaran, melatih sportifitas, menumbuhkan rasa empati, dan membantu aspek psikologis anak. 
Berdasarkan hasil Penelitian diambil rekomendasi sebagai berikut:

Bagi orang tua untuk menambah wawasan pengetahuan agama dan umum. Lebih banyak lagi dalam mendampingi dan mengajarkan kebaikan-kebaikan pada anak untuk menumbuhkan karakter yang baik. Lebih banyak lagi perhatian pada anak, sehingga anak merasa dekat dan percaya pada orang tua. Dapat mengontrol penggunaan HP pada anak dengan cara mengurangi pemakaian HP saat bersama anak.

Bagi anak untuk meningkatkan wawasan dan pengetahuan agama dan umum. Mengurangi bermain game online dan lebih banyak memainkan permainan tradisional, sehingga permainan tradisional tidak punah dan tetap lestari. Meningkatkan kepekaan dan kepedulian sosial pada teman, karena akan berdampak pada diri sendiri juga.

\section{DAFTAR PUSTAKA}

Adi, C. W. (2016). Penanaman Kepedulian Sosial di MTs SatuAtap Hidayatul Mubtadi'in Kalitapen Kecamatan Purwojati Kabupaten Banyumas. Skripsi Publikasi. IAIN Purwokerto.

Agung, dan Asmira. (2018). Pengembangan Model Pendidikan Karakter Peduli Sosial Melalui MetodeBermain Peran di TK Tunas Mekar Indonesia Bandar Lampung. Jurnal Caksaka-Pendidikan Anak Usia Dini.1 (2)

Andayani, dan Majid. (2013). Pendidikan Karakter Perspektif Islam. Bandung: PT. Remaja Rosdakarya.

Aqib, dan Sujak. (2011). Panduan dan Aplikasi Pendidikan Karakter. Bandung: Penerbit Yrama Widya.

Asmani, J. M. (2011). Tuntunan Lengkap Metodologi Praktis Penelitian Pendidikan. Jogjakarta: DIVA Press.

Badan Penelitian dan Pengembangan Pusat Kurikulum. (2010). 18 Nilai - Nilai Karakter. Jakarta: Kemendiknas.

Baron, dan Byrne. (2004). Psikologi Sosial. Jakarta: Penerbit Erlangga.
Fauzi, A. R. (2017). Penguatan Karakter Rasa InginTahu dan Peduli Sosial Melalui Discovery Learning. JTP2IPS, 2 (2), 27-36.

Fauziah, M. I. (2013). Pengembangan Modifikasi Permainan Gobak Sodor Dalam Bimbingan Kelompok Untuk Afiliasi Diri Antar Siswa SMP Kelas VII. Jurnal Bimbingan Konseling Fakultas Ilmu Pendidikan Universitas Negeri Surabaya.

Handoyo, dan Yudiwinata. (2014). Permainan Tradisional dalam Budaya. Paradigma. 02 (03).

Hardiyanti, dan Lutfi. (2013). Meningkatkan Hasil Belajar Siswa pada Pembelajaran Unsur dan Senyawa Kimia Sederhana dengan Menggunakan Media Permainan Tradisional Gobak Sodor. Unesa Journal of Chemical Education. 2 (2) 7-11.

Harly, S. L., dkk. (2014). Peningkatan Perkembangan Sosial Emosional Melalui Metode Bermain Permainan Tradisional. FKIP Untan.

Iswinarti. (2017). Permainan Tradisional: Prosedur dan Analisis Manfaat Psikologis. Malang: Penerbit Universitas Muhammadiyah Malang.

Kesuma, D. (2013). Pendidikan Karakter Untuk Bangsa. Jakarta: PT. Bumi Aksara.

Kurniati, E. (2016). Permainan Tradisional dan Perannya dalam Mengembangkan Keterampilan Sosial Anak. Jakarta: Prenada Media.

Megawangi, R. (2004). Pendidikan Karakter Solusi yang Tepat untuk Membangun Bangsa. Jakarta: Indonesia Heritage Foundation.

Muslich, M. (2013). Pendidikan Karakter Menjawab Tantangan Krisis Multidimensional. Jakarta: Bumi Aksara.

Nur, H. (2013). Membangun Karakter Anak Melalui Permainan Anak Tradisional. Jurnal Pendidikan Karakter, 1 (III). 
Sugiyono, (2016). Metode Penelitian Pendidikan. Bandung: Alfabeta.

Sukmadinata, N. S. (2013). Metode Penelitian Pendidikan. Bandung: PT. Remaja Rosdakarya.

Suyadi. (2013). Strategi Pembelajaran Pendidikan Karakter. Jakarta: Prenada Media.

Tabi'in. (2017). Menumbuhkan Sikap Peduli Pada Anak Melalui Interaksi Kegiatan Sosial. Jurnal IJTIMAIYA, 1 (1).

Uno, H, dkk. (2016). Landasan Pendidikan. Jakarta: PT. Bumi Aksara.

Utami, H. D. (2011). Penanaman Sikap Sosial Melalui Pembelajaran IPS pada Siswa Kelas V. Jakarta: UHAMKA. 